American Journal of Environmental Sciences 5 (1): 106-110, 2009

ISSN 1553-345X

(C) 2009 Science Publications

\title{
Exploring the Reuse Potential of Chemical Sludge from Textile Wastewater Treatment Plants in India-A Hazardous Waste
}

\author{
${ }^{1}$ Hema Patel and ${ }^{2}$ Suneel Pandey \\ ${ }^{1}$ India Habitat Centre, TERI University, Lodhi Road, New Delhi, India \\ ${ }^{2}$ Centre for Regulatory and Policy Research, The Energy and Resources Institute, \\ India Habitat Centre, New Delhi, India
}

\begin{abstract}
Problem statement: This study was conducted to explore the reuse potential of the chemical sludge (considered as hazardous waste as per Indian Government Hazardous Waste Management Rules) generated from combined effluent treatment in textile clusters. These textile clusters mainly cover the cotton dyeing and printing operations. Approach: Therefore, treatability studies of chemical sludge were conducted using solidification/stabilization treatment to examine the possibility of its reuse in construction materials. The sludge was characterised for its physico-chemical parameters and heavy metals. Standard blocks of dimensions $70.6 \times 70.6 \times 70.6 \mathrm{~mm}$ were prepared, in which chemical sludge was used as a partial replacement of cement by mixing 30-70\% of sludge in cement. After the experimental curing, the blocks were evaluated for physical engineering properties such as hardening time, block density, unconfined compressive strength. The chemical properties were determined in terms of concentrations of heavy metals in the TCLP leachate. Results: The hardening time ranged between $30-45 \mathrm{~h}$. The compressive strength in the sludge cement blocks ranged from 2.63$22.54 \mathrm{~N} \mathrm{~mm}^{-2}$ after 14 days of water curing and $6.48-24.89 \mathrm{~N} \mathrm{~mm}^{-2}$ after 28 days of water curing for $30,40,50,60$ and $70 \%$ sludge replacement in cement. The block density varied between 1361. 3408$1813.8992 \mathrm{Kg} \mathrm{m}^{-3}$ after 14 days and $1386.3953-1842.3446 \mathrm{Kg} \mathrm{m}^{-3}$ after 28 days of water curing. The concentrations of heavy metals were negligible in the TCLP leachate and thus below USEPA regulatory limits. Conclusion/Recommendations: As far as structural applications is concerned, it is fulfilling the criteria of some of the classes (C to K) as per the BIS standards of the bricks upto a strength of $25 \mathrm{~N} \mathrm{~mm}^{-2}$. The use of sludge can definitely be explored for other structural and nonstructural applications depending upon strength requirement. Other applications of textile sludge in the construction materials to be explored by conducting more bench scale studies.
\end{abstract}

Key words:Textile industry, chemical sludge, wastewater, construction, reuse, compressive strength

\section{INTRODUCTION}

Solidification/Stabilization technologies (S/S) are widely used for the treatment of hazardous wastes that are mostly inorganic (aqueous wastes, sludges, slags and ashes containing hazardous metals) and contaminated soils before their final disposal. The method has been designated as the Best Demonstrated Available Technology (BDAT) for some wastes and waste forms ${ }^{[3]}$. Stabilization is the process where additives are mixed with waste to minimize the rate of contaminant migration from the waste and to reduce the toxicity of waste. Solidification is a process employing additives which physical nature of the waste (as measured by the engineering properties of strength, compressibility and/or permeability) is altered during the process. Thus the objectives of solidification and stabilization would be to reduce the toxicity of waste as well as to improve the engineering properties of the waste.

The type of S/S processes available can be broken into six major categories:

1. Cement based binders

- Portland cement

- Cement kiln dust

- Fly ash mixtures

2 Lime based binders

- Lime

- Lime kiln dust

- Mixtures of fly-ash and lime

Corresponding Author: Hema Patel, TERI University, Darbari Seth Block, India Habitat Centre, Lodhi Road, New Delhi, 110 003, India 
3. Adsorbents

- Hydro and organophillic clays

- Wood chips, sawdust, rice hulls

4. Thermoplastic materials

- Asphalt bitumen

- Thermoplastic polymer

5. Thermosetting polymers

6. Vitrification

Cement based binders have been most commonly used for the treatment of many types of wastes mostly inorganic sludges containing heavy metals. Portland cement is most widely used for $\mathrm{S} / \mathrm{S}$ as a binder material. It is not used alone but was used as a major ingredient in a number of $S / S$ processes. Many formulations have been developed for the S/S process according to different types of wastes. This indicates that Portland cement can be modified for suitable S/S process using fly ash, lime, slag soluble silicates and clay.

In India, nearly 290 million tonnes of industrial wastes are generated annually ${ }^{[4]}$ of which around 7.2 million tonnes is hazardous and require careful disposal. Saxena ${ }^{[6]}$ studied the use of copper tailings up to $50 \%$ in replacement of clay for the manufacturing of bricks and found that the properties of these bricks meeting the Bureau of Indian Standards (BIS) for the bricks. Singh ${ }^{[8]}$ reported the use of beneficiated phosphor-gypsum (a by product of gypsum) in the manufacture of building materials like semi-hydrated plasters and plaster products, fibrous gypsum plaster boards, gypsum blocks, slotted paving and gypsum tiles. The paving tiles of $300 \times 300 \times 20 \mathrm{~mm}$ met the properties of BIS standards. Sengupta et al..$^{7]}$ investigated the use of petroleum ETP sludge for the manufacture of bricks and found out that met the relevant BIS standards.

The textile chemical sludge is generated in huge quantity after physico-chemical treatment using lime and ferrous sulphate in Common Effluent Treatment Plants (CETPs) treating textile wastewater. Presently it is either disposed in landfills or is dumped without any suitable treatment.

The aim of the present study was to have an economic and environmentally safe management option for chemical sludge generated from effluent treatment in textile dyeing industry. The characterisation of sludge was done for the physico-chemical parameters and heavy metals. Treatability studies of textile sludge were conducted using solidification/stabilization as the treatment option to examine the possibility of its use in construction material. The evaluation of the solidified blocks was done in terms of the physical characteristics such as unconfined compressive strength, hardening time and block density as per the BIS standards as well as the chemical properties of the leachate in terms of heavy metals concentrations.

\section{MATERIALS AND METHODS}

Collection of chemical sludge samples: The sludge was obtained from Common Effluent Treatment Plant in Balotra in Barmer district of Rajasthan state. The CETP at Balotra receives wastewater mainly from 600 cotton dyeing and printing units. The total flow discharge from these industries is $13,925 \mathrm{Kl} / \mathrm{d}$ from which 55.76 tonnes/d chemical sludge is generated from the physico-chemical treatment process ${ }^{[5]}$. Grab sample of sludge was collected in wide mouth polypropylene jars and consequently the samples were refrigerated at $4^{\circ} \mathrm{C}$ for storage.

Characterisation of sludge: The chemical sludges were characterised for various physico-chemical parameters and heavy metals using standard methods such as BIS, APHA methods and CPCB solid waste manual. The physico-chemical properties and heavy metals of CETP sludge are shown Table 1.

Solidification/stabilisation experiments: The sludge was dried in a hot air oven for $24 \mathrm{~h}$ at $100^{\circ} \mathrm{C}$. After drying, the sludge was powdered in a ball mill and then was passed through $212 \mu$ BSS sieve. Mortar cube steel moulds of $70.6 \times 70.6 \times 70.6 \mathrm{~mm}$ size were used to make the blocks. The physical and chemical properties of OPC are given in Table 2. The blocks were prepared as per the BIS standard IS 4031(6).

Table 1: Physico-chemical characterization of chemical sludge generated from treatment of textile dyeing wastewater at Balotra

\begin{tabular}{lr}
\hline Parameter & Value \\
\hline pH & 8.70 \\
Electrical conductivity $\left(\mathrm{mS} \mathrm{m}^{-1}\right)$ & 6.90 \\
Moisture content $(\%)$ & 10.50 \\
Total solids (\%) & 89.50 \\
Total Volatile Solids (\% of dry solids) & 36.60 \\
Total fixed solids (\% of dry solids) & 63.40 \\
Total Organic Carbon $(\%)$ & 11.20 \\
Calorific value $\left(\mathrm{Kcal} \mathrm{kg}^{-1}\right)$ & 991.57 \\
Density $\left(\mathrm{Kg} \mathrm{m}^{-3}\right)$ & 916.23 \\
Specific gravity & 0.94 \\
$\mathrm{Cd}\left(\mathrm{mg} \mathrm{kg}^{-1}\right)$ & 5.17 \\
$\mathrm{Cu}\left(\mathrm{mg} \mathrm{kg}^{-1}\right)$ & 225.48 \\
$\mathrm{Zn}\left(\mathrm{mg} \mathrm{kg}^{-1}\right)$ & 186.47 \\
$\mathrm{Ni}\left(\mathrm{mg} \mathrm{kg}^{-1}\right)$ & 89.67 \\
$\mathrm{Co}\left(\mathrm{mg} \mathrm{kg}^{-1}\right)$ & 11.20 \\
$\mathrm{~Pb}(\mathrm{mg} \mathrm{kg}$ & \\
$\mathrm{Cr}(\mathrm{III})\left(\mathrm{mg} \mathrm{kg}^{-1}\right)$ & 44.75 \\
$\mathrm{Cr}(\mathrm{VI})\left(\mathrm{mg} \mathrm{kg}^{-1}\right)$ & 231.45 \\
\hline
\end{tabular}


Mixture of dry sludge and cement were made with a trowel for $1 \mathrm{~min}$ and then water was poured until the mixture was uniform in colour and then poured this mixture in mould and immediately after casting each layer, prod with a rod 20 times in about $8 \mathrm{~s}$ to ensure elimination of entrained air. The filled moulds were kept in moist conditions for $24 \mathrm{~h}$.

At the end of this period, the blocks were removed from the moulds and put blocks in clean fresh water, maintained at $27^{\circ} \mathrm{C}$ for curing. The sludge was used in ratio of $0 \%$ (control), 30, 4050,60 and $70 \%$ as a partial replacement of cement. The water content in the cement sludge paste was varying from $21-35 \%$ for $30-70 \%$ sludge replacement. Triplicate of each sample ratio was prepared. The samples were subjected to 14 days and 28 days water curing. The samples were cured at ambient temperature and Relative Humidity (RH) of $70 \%$.

\section{Physical Engineering evaluation of blocks}

Hardening time: Hardening time was determined by visual observation and hand-pressing the specimen every $6 \mathrm{~h}$.

Unconfined compressive strength (UCS): UCS values of cement-sludge paste cubes were measured by compression testing machine as per BIS specification code IS 4031(6) ${ }^{[1]}$. Total maximum loads were recorded at the point of fracture and the compressive strength was determined using the formula.

$$
\mathrm{Fm}=\mathrm{P} / \mathrm{A}
$$

Where:

$\mathrm{Fm}=$ Compressive strength (in $\mathrm{N} \mathrm{mm}^{-2}$ )

$\mathrm{P}=$ Total maximum load (in $\mathrm{N}$ )

$\mathrm{A}=$ Area of loaded surface $\left(\right.$ in $\mathrm{mm}^{2}$ )
Compressive strength was calculated by taking the average of three replicates for each test. The block density were also measured as per the BIS Specification code IS 2185 (Part I)-1979 ${ }^{[2]}$. The nomenclature and its description for OPC blocks is mentioned in Table 3.

TCLP test for sludge-cement blocks: Toxicity Characteristic Leaching Procedure (TCLP) of cementsludge blocks were conducted. After 28 days of curing, the samples of cubes were crushed to $<9.5 \mathrm{~mm}$ in size. Each crushed sample was treated with an acetic acid solution of $\mathrm{pH} 2.88$ at a liquid-to-solid ratio of 20:1 for a period of $18 \mathrm{~h}$ in the bottles. The bottles were tumbled at $28-30 \mathrm{rpm}$ at room temperature for $18 \mathrm{~h}$. At the end of the extraction, the leachate were filtered through a $0.45 \mu \mathrm{m}$ membrane filter to remove suspended solids. The filtered leachate was analysed on atomic absorption spectrometer (AAS) for the heavy metals.

Table 2: Physical and chemical properties of OPC

\begin{tabular}{lc}
\hline Parameter & Value (\%) \\
\hline Chemical analysis & 63.50 \\
Lime $(\mathrm{CaO})$ & 19.05 \\
$\mathrm{Silica}\left(\mathrm{SiO}_{2}\right)$ & 4.20 \\
Alumina $\left(\mathrm{Al}_{2} \mathrm{O}_{3}\right)$ & 3.10 \\
Iron oxide $\left(\mathrm{Fe}_{2} \mathrm{O}_{3}\right)$ & 2.90 \\
Magnesia $(\mathrm{MgO})$ & 2.50 \\
Sulphur trioxide $\left(\mathrm{SO}_{3}\right)$ & 0.90 \\
Soda and/or potash $\left(\mathrm{Na}_{2} \mathrm{O}+\mathrm{K}_{2} \mathrm{O}\right)$ & 2.10 \\
Loss on ignition & \\
Physical tests & 28.00 \\
Consistency of standard cement paste & $3.5 \mathrm{~mm}$ \\
Soundness of cement & $125.0 \mathrm{~min}$ \\
Initial setting time of cement & $182.0 \mathrm{~min}$ \\
Final setting time of cement & $2698 \mathrm{~cm}^{2} \mathrm{~g}^{-1}$ \\
Fineness by air permeability & \\
Compressive strength of $50 \mathrm{~cm}^{2}$ cube & \\
3 day-24.8 MPa & \\
7 day-34.4 MPa & \\
28 day- $45.9 \mathrm{MPa}$ &
\end{tabular}

Table 3: Nomenclature of sludge/cement mixtures studied

OPC as binder systems in 14 days water curing

OPC $-\mathrm{CN}-14-\mathrm{W}$

OPC - 30- 14-W

OPC - 40-14-W

OPC $-50-14-\mathrm{W}$

OPC-60-14-W

OPC-70-14-W

OPC as binder systems in 28 days water curing

OPC - CN-28-W

OPC - 30-28-W

OPC- 40-28-W

OPC-50-28-W

OPC-60-28-W

OPC-70-28-W

$0 \%$ Sludge, $100 \%$ OPC, 14 days water curing $30 \%$ Sludge, $70 \%$ OPC, 14 days water curing $40 \%$ Sludge, $60 \%$ OPC, 14 days water curing $50 \%$ Sludge, 50\% OPC, 14 days water curing $60 \%$ Sludge, $40 \%$ OPC, 14 days water curing $70 \%$ Sludge, $30 \%$ OPC, 14 days water curing

$0 \%$ Sludge, $100 \%$ OPC, 28 days water curing $30 \%$ Sludge, $70 \%$ OPC, 28 days water curing $40 \%$ Sludge, $60 \%$ OPC, 28 days water curing $50 \%$ Sludge, 50\% OPC, 28 days water curing $60 \%$ Sludge, $40 \%$ OPC, 28 days water curing $70 \%$ Sludge, $30 \%$ OPC, 28 days water curing 
Am. J. Environ. Sci., 5 (1): 106-110, 2009

Table 4: The mix proportions and compressive strengths of cement-sludge blocks

\begin{tabular}{lcclllc}
\hline & Sludge & Cement & Total wt. & Water & Water & Compressive \\
Block ID & $(\mathrm{g})$ & $(\mathrm{g})$ & $(\mathrm{g})$ & $(\mathrm{mL})$ & Sludge+-cement & Strength $\left(\mathrm{N} \mathrm{mm} \mathrm{mm}^{-2}\right)$ \\
\hline OPC-CN-14-W & 0 & 700 & 700 & 145 & 0.21 & 53.46 \\
OPC-30-14-W & 180 & 420 & 600 & 163 & 0.27 & 22.54 \\
OPC-40-14-W & 240 & 360 & 600 & 170 & 0.28 & 16.50 \\
OPC-50-14-W & 300 & 300 & 600 & 185 & 0.31 & 10.73 \\
OPC-60-14-W & 360 & 240 & 600 & 205 & 0.34 & 6.78 \\
OPC-70-14-W & 420 & 180 & 600 & 210 & 0.35 & 2.63 \\
OPC-CN-28-W & 0 & 700 & 700 & 145 & 0.21 & 65.81 \\
OPC-30-28-W & 180 & 420 & 600 & 163 & 0.27 & 24.89 \\
OPC-40-28-W & 240 & 360 & 600 & 170 & 0.28 & 20.54 \\
OPC-50-28-W & 300 & 300 & 600 & 185 & 0.31 & 14.41 \\
OPC-60-28-W & 360 & 240 & 600 & 205 & 0.34 & 8.39 \\
OPC-70-28-W & 420 & 180 & 600 & 210 & 0.35 & 6.48 \\
\hline
\end{tabular}

Table 5: Block density of solidified products at 28 day curing

\begin{tabular}{lll}
\hline & \multicolumn{1}{c}{ Block density $\left(\mathrm{kg} \mathrm{m}^{-3}\right)$} \\
\hline------- \\
Block ID & 14 days & 28 days \\
\hline 0\% Sludge, 100\% OPC & 2008.86 & 2005.73 \\
30\% Sludge, 70\% OPC & 1813.90 & 1842.34 \\
40\% Sludge, 60\% OPC & 1671.07 & 1679.47 \\
50\% Sludge, 50\% OPC & 1586.44 & 1579.21 \\
60\% Sludge, 40\% OPC & 1474.03 & 1489.36 \\
70\% Sludge, 30\% OPC & 1361.34 & 1386.40 \\
\hline
\end{tabular}

\section{RESULTS}

The physico-chemical characterization of chemical sludge is presented in Table 1. The solidified blocks were evaluated for physical engineering properties. Hardening time ranged between 30-45 h. The control samples, containing $100 \%$ cement (with no sludge replacement) were cured within $24 \mathrm{~h}$. The mix proportions of the cement-sludge blocks and the compressive strength is given in Table 4. The compressive strength in sludge-cement blocks after 14 and 28 days of curing ranged from $2.63-22.54 \mathrm{~N} \mathrm{~mm}^{-2}$ and $6.48-24.89 \mathrm{~N} \mathrm{~mm}^{-2}$ for $30,40,50,60$ and $70 \%$ sludge replacement in cement. The control gave a strength of 53.46 and $65.81 \mathrm{~N} \mathrm{~mm}^{-2}$ after 14 and 28 days of water curing.

The block density data is presented in Table 5 . It varied between 1361.3408-1813.8992 $\mathrm{kg} \mathrm{m}^{-3}$ (corresponding to 30 and $70 \%$ sludge replacement) after 14 days and 1386.3953-1842.3446 Kg m${ }^{-3}$ after 28 days of curing.

\section{DISCUSSION}

From the physico-chemical properties, it is evident that sludge is alkaline in nature with high electrical conductivity values. The volatile soilds of sludge is such that it can not be used for incineration as it would result in very high ash content. Among the heavy metals analysed, $\mathrm{Cu}, \mathrm{Ni}, \mathrm{Zn}$ and $\mathrm{Cr}$ are found to be in high concentrations as compared to other heavy metals. When compared with the regulatory limits mentioned in the Hazardous waste management (amendment) rules 2003, all the heavy metals are found to be within the limits still there has to be an alternative option for its treatment, reuse and final disposal. Therefore, treatability studies using solidification/stabilization were conducted.

In case of compressive strength measurement, it has been reduced as the percentage replacement of sludge in cement was increased as indicated by Fig. 1. The maximum compressive strength was found in case of control samples with only cement. The longer the material was cured, the stronger the solidified matrix became for all treatments including control. The blocks after 14 days of curing had achieved $40-90 \%$ of the strength achieved after 28 days of curing. When compared with standards for different types of construction materials, i.e. in case of brick which is available in the range of $3.5-35 \mathrm{~N} \mathrm{~mm}^{-2}$, the strength of the solidified sludge-cement blocks were found to be in the range of $6.5-25 \mathrm{~N} \mathrm{~mm}^{-2}$ conforming to 9 classes of bricks. There are other building materials also like hollow and solid concrete blocks having requiring strength 5 and $4 \mathrm{~N} \mathrm{~mm}^{-2}$ and hollow and solid light weight concrete blocks having strength 10.8 and $7.0 \mathrm{~N}$ $\mathrm{mm}^{-2}$, soil based blocks requiring compressive strength of $2 \mathrm{~N} \mathrm{~mm}$, lime-pozzolona concrete blocks for paving requiring compressive strength of $3.5 \mathrm{~N} \mathrm{~mm}^{-2}$. Therefore considering the strength requirements for these construction materials, the cement-sludge blocks fulfill the requirements for most of the materials for non-structural purposes.

As far as the block density is concerned, the blocks having $100 \%$ cement is having the maximum bulk density and as the percentage of sludge is increasing in the blocks, the block density is reducing. The block density for 14 days strength and 28 days was almost the same. 


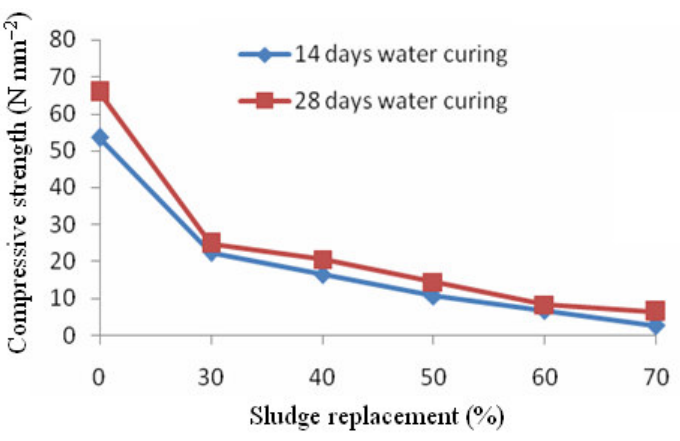

Fig. 1: Compressive strength plotted as a function of percentage of sludge replacement

The maximum block density was for the one having $100 \%$ cement is $2008.8647 \mathrm{~kg} \mathrm{~m}^{-3}$ after 14 days and $2005.7284 \mathrm{~kg} \mathrm{~m}^{-3}$ for 28 days. The block density requirements of the blocks are $1800 \mathrm{~kg} \mathrm{~m}^{-3}$ for solid concrete blocks and $1600 \mathrm{~kg} \mathrm{~m}^{-3}$ for hollow and solid light weight concrete blocks and $1000 \mathrm{~kg} \mathrm{~m}^{-3}$ for lime based blocks. Therefore the solidified blocks are also fulfilling the block density requirements for different types of building materials.

The heavy metal concentrations in the leachate were compared with US EPA regulatory limits and were found to be in negligible as compared to the stipulated limits. Therefore there is no significant leaching of heavy metals from the cement-sludge blocks.

\section{CONCLUSION}

The treatability studies using solidification/stabilization indicates that chemical sludge generated from treatment of textile dyeing wastewater has the possibility to be used as the construction material. As far as the structural applications is concerned, it is fulfilling the criteria of some of the classes (C to $\mathrm{K}$ ) as per BIS Standards of the bricks upto a strength of $25 \mathrm{~N} \mathrm{~mm}^{-2}$. The use of sludge can definitely be explored for other structural and nonstructural applications depending upon the requirement of strength. It can be used for applications such as for both load-bearing and non-load bearing walls, for partitions and panel walls, as backing for other types of facing materials, for piers, pilasters and columns, for retaining walls, garden walls, chimneys and fire places, as fillers in concrete joist floor construction and as shuttering for beams, columns and lintels. Negligible concentrations of heavy metals were found in the TCLP leachate. Therefore the chemical sludge from textile wastewater treatment plants has a potential to be reused as construction materials of different applications. As an extension of the work, some more applications of textile sludge to be explored by conducting more bench scale studies.

\section{ACKNOWLEDGEMENT}

The researchers are thankful to the CETP personnel of Balotra, Rajasthan for providing the necessary samples and to TERI staff for the assistance technical and financial support.

\section{REFERENCES}

1. Bureau of Indian Standard, 1988. Methods for hydraulic cement-Determination of compressive strength of hydraulic cement. http://www.bis.org.in/bis/html/4031_6.html.

2. Bureau of Indian standard, 2005. Methods of testing for cement masonry units-Hollow bricks and solid blocks. http://www.bis.org.in/ bis/html/2158_1.html.

3. Conner, J.R., 1990. Chemical Fixation and Solidification-of-Hazardous-Waste. 1st Edn., Van Nostrand, Reihold, New York, USA., ISBN: 10: 0442205112, pp: 692.

4. Pappu, A., M. Saxena and S.R. Asolekar, 2007. Solid waste generation in India and there recycling potential in building material. Build. Environ., 42: 2311-2320. DOI: 10.1016/j.buildenv.2006.04.015.

5. Patel, H. and S. Pandey, 2008. Physico-chemical characterisation of textile chemical sludge generated from various CETPs, in India. J. Environ. Res. Develop., 2: 329-339. http://www.jerad.org/

JRDAbsRead.asp?SNoid=114.

6. Saxena, M., V.S. Gouri, J. Prabhakar and T. Sangeeta, 2002. Innovative building materials: Polymer composites, copper tailing bricks and blue dust primer. Civil Eng. Construct. Rev., 15: 46-50.

7. Sengupta, P., N. Saikia and P.C. Borthakur, 2002. Bricks from petroleum treatment sludge: Properties and environmental characteristics. J. Environ. Eng., 128: $\quad$ 1090-1094. http://scitation.aip.org/ getabs/servlet/GetabsServlet?prog=normal\&id=JO EEDU000128000011001090000001\&idtype $=$ cvips \&gifs=yes.

8. Singh, M., 2002. Value added products from Industrial waste. Civil Eng. Construct. Rev., 15: 36 . 